\title{
ОСОБЛИВОСТІ БІОІМПЕДАНСОМЕТРІЇ У ХВОРИХ НА ХРОНІЧНИЙ ПАНКРЕАТИТ ТА АТЕРОСКЛЕРОЗ
}

\author{
๑є. С. Сірчак, С. М. Опаленик, Н. Ю. Курчак \\ ДВНЗ «Ужгородський національний університет»
}

РЕЗЮМЕ. У статті описано та проаналізовано результати біоімпедансометрії у хворих на хронічний панкреатит та атеросклероз.

Мета - дослідити особливості біоімпедансометрії у хворих на хронічний панкреатит (ХП) та атеросклероз.

Матеріал і методи. У дослідження включено 60 хворих на ХП віком від 40 до 60 років. Контрольну групу склали 20 практично здорових осіб віком від 40 до 60 років. Залежно від наявності порушень у ліпідограмі всіх хворих було поділено на дві групи. До першої увійшли 28 хворих на ХП без атеросклеротичних змін, до другої 32 хворих на ХП й атеросклероз. Всім пацієнтам було проведено дослідження ліпідного спектра крові з визначенням рівня загального холестерину плазми крові (3Х), тригліцеридів (ТГ), холестерину ліпопротеїдів високої щільності (ЛПВЩ) і ліпопротеїдів низької щільності (ЛПНЩ), коефіцієнта атерогенності (КА). Крім того, всім хворим було проведено біоімпедансне дослідження складу тіла з визначенням рівня жирової, м'язової, кісткової маси, рідини в організмі та обчисленням індексу маси тіла (IMT). Для інтерпретації результатів дослідження всіх хворих було поділено за статтю на підгрупи.

Результати. Отримані результати вказують на те, що у хворих на ХП та атеросклероз навіть при нормальному показнику IMT спостерігається ожиріння за результатами біоімпедансного дослідження складу тіла, що супроводжується тяжчим перебігом захворювання та несприятливим прогнозом. Тому до комплексу заходів із діагностики ХП необхідно включати не тільки визначення показників ліпідного обміну та ІМТ, а й дослідження складу тіла.

Висновки. В ході дослідження було виявлено дефіцит маси тіла за результатами біоімпедансного обстеження та IMT у хворих на хронічний панкреатит без атеросклеротичних змін. У хворих на хронічний панкреатит та атеросклероз було встановлено «приховане» ожиріння за результатами біоімпедансометрії при нормальному значенні ІМТ.

КлючовІ СлОВА: хронічний панкреатит; атеросклероз; біоімпедансне дослідження.

Вступ. Хронічний панкреатит (ХП) є прогресуючим запальним розладом, що викликає необоротні зміни в тканині підшлункової залози та призводить до порушення харчування у пацієнтів. Тяжкість діагностики створюють коморбідні патології, які ускладнюють одна одну та погіршують якість життя таких пацієнтів $[1,2]$.

Діагностика складу тіла часто обмежується визначенням індексу маси тіла та деяких інших антропометричних показників. Проте орієнтація лише на масо-зростові показники може дати неправильне уявлення про вміст жиру в організмі у випадку атрофії скелетної мускулатури (у зв'язку з віком чи гіподинамією), порушень водно-електролітного балансу при розвиненій мускулатурі (у спортсменів) [3].

Біоімпедансометрія - це метод визначення співвідношення тканин організму шляхом вимірювання їх електричного опору з подальшою комп'ютерною обробкою даних результатів, який може використовуватися як інструмент скринінгу у хворих на ХП та атеросклероз $[2,4]$. Саме тому для об'єктивної оцінки та більш чіткої діагностики стану пацієнтів важливим $є$ визначення кількісного складу тіла за допомогою біоімпедансометрії.

Мета роботи - дослідити особливості біоімпедансометрії у хворих на хронічний панкреатит та атеросклероз.
Матеріал і методи дослідження. У дослідження включено 60 хворих на ХП, які перебували на стаціонарному лікуванні в гастроентерологічному та ендокринологічному відділенні ЗОКл ім. А. Новака м. Ужгорода, та хворих, які перебували на амбулаторно-диспансерному спостереженні у дільничного сімейного лікаря за місцем проживання. Вік хворих становив від 40 до 60 років (середній - $(51,14 \pm 1,05)$ року). Контрольну групу склали 20 практично здорових осіб (ПЗО) віком від 40 до 60 років (середній - (54,65士 2,16) року).

Діагноз ХП встановлювали відповідно до марсельсько-римських критеріїв (1989 р.) із доповненнями Я. С. Циммермана (1995 р.) та уточненнями МKX-10.

Дисліпідемічні порушення виявляли, аналізуючи показники ліпідного обміну (загальний холестерин (3X), ліпопротеїди високої щільності (лПВЩ), ліпопротеїди низької щільності (ЛПнщ), ліпопротеїди дуже низької щільності (лпднщ), індекс атерогенності). Коефіцієнт атерогенності (KA) обчислювали за формулою: КА = (загальний XС - ЛПВЩ)/ЛПВЩ. Залежно від наявності порушень у ліпідограмі всіх хворих було поділено на дві групи. До першої (I) увійшли 28 хворих на ХП без атеросклеротичних змін, до другої (II) - 32 хворих на ХП й атеросклероз. 
Огляди літератури, оригінальні дослідження, погляд на проблему, ювілеї

Біоімпедансне дослідження складу тіла проводили на аналізаторі Momert 7 (модель 5863) шляхом аналізу біоелектричного опору (АБО). За допомогою АБО визначали вміст жирової, м'язової, кісткової маси та рідини в організмі. Усім хворим обчислювали індекс маси тіла (IMT) за формулою: IMT = маса (кг) : зріст $\left(\mathrm{M}^{2}\right)$. За норму вважали показники, наведені у таблиці 1 окремо для чоловіків та жінок. Для інтерпретації результатів дослідження всіх хворих було поділено за статтю на підгрупи. У I групі було 11 (39,3 \%) чоло- віків та 17 (60,7 \%) жінок, у ІІ групі - 14 (43,8 \%) чоловіків та 18 (56,3 \%) жінок відповідно. У групі ПЗО була однакова кількість чоловіків та жінок.

Методика проведення всіх досліджень відповідала Гельсінській декларації 1975 р. та її перегляду 1983 р. Аналіз і обробку результатів о6стеження хворих здійснювали за допомогою комп'ютерної програми STATISTICA 10.0 (фірми StatSoft Inc, USA) з використанням параметричних та непараметричних методів оцінки отриманих результатів.

Таблиця 1. Нормальні значення біоімпедансометрії

\begin{tabular}{|c|c|c|}
\hline Показник & Чоловіки віком 40-60 років & Жінки віком 40-60 років \\
\hline ІМТ & $20,0-24,9$ & $20,0-24,9$ \\
\hline Жирова маса, \% & $11,0-22,0$ & $23,0-35,0$ \\
\hline М'язова маса, кг & $39,0-50,0$ & $29,0-36,0$ \\
\hline Кісткова маса, \% & Більше 10,0 & Бідьше 10,0 \\
\hline Вміст рідини & $47,0-61,0$ & $43,0-52,0$ \\
\hline
\end{tabular}

Результати й обговорення. Усім хворим було проведено біохімічне дослідження крові 3 визначенням показників ліпідограми. У таблиці 2 наведено середні значення ліпідограми по групах, а також дані контрольної групи (p<0,05).

Як видно з таблиці, у ліпідограмі пацієнтів II групи відмічаються зрушення у вигляді гіперхолестеринемії $((6,91 \pm 1,11)$ ммоль/л), гіпертриглі- церидемії $((2,6 \pm 0,43)$ ммоль/л), підвищення лПнЩ (до $(4,4 \pm 0,62)$ ммоль/л) та зниження рівня антиатерогенних лПВЩ (до $(0,9 \pm 0,19)$ ммоль/л) відповідно. Необхідно відмітити, що показники ліпідного профілю у хворих на ХП I групи перебувають у межах норми, проте вони є статистично достовірно вищими, порівняно з контрольною групою ПЗО.

Таблиця 2. Показники ліпідного обміну у хворих на ХП та контрольної групи

\begin{tabular}{|c|c|c|c|}
\hline Показник & $\begin{array}{c}\text { Контрольна група } \\
(\mathrm{n}=20)\end{array}$ & $\begin{array}{c}\text { Хворі на ХП без } \\
\text { атеросклеротичних змін } \\
(\mathrm{n}=28)\end{array}$ & $\begin{array}{c}\text { Хворі на ХП з } \\
\text { атеросклеротичними змінами } \\
(\mathrm{n}=32)\end{array}$ \\
\hline ТГ, ммоль/л & $1,02 \pm 0,25$ & $1,61 \pm 0,04$ & $2,6 \pm 0,43$ \\
\hline ЗХ, ммоль/л & $3,31 \pm 0,35$ & $4,22 \pm 0,31$ & $6,91 \pm 1,11$ \\
\hline лПНЩ, ммоль/л & $3,0 \pm 0,13$ & $3,2 \pm 0,18$ & $4,4 \pm 0,62$ \\
\hline лПДНЩ, ммоль/л & $0,17 \pm 0,47$ & $0,32 \pm 0,2$ & $1,8 \pm 0,32$ \\
\hline лПВЩ, ммоль/л & $2,2 \pm 0,01$ & $2,0 \pm 0,02$ & $0,9 \pm 0,19$ \\
\hline КА & $1,36 \pm 0,74$ & $1,6 \pm 0,18$ & $4,78 \pm 0,26$ \\
\hline
\end{tabular}

Крім того, всім хворим на ХП було проведено біоімпедансне дослідження складу тіла з визначенням вмісту жирової, м'язової, кісткової маси, рідини в організмі та обчисленням індексу маси тіла (IMT). У таблиці 3 наведено результати даного обстеження.

Таблиця 3. Результати біоімпедансного дослідження у хворих на ХП по групах та контрольної групи

\begin{tabular}{|l|c|c|c|c|c|c|}
\hline \multirow{2}{*}{ Показник } & \multicolumn{2}{|c|}{ І група } & \multicolumn{2}{c|}{ II група } & \multicolumn{2}{c|}{ ПзО } \\
\cline { 2 - 7 } & $\begin{array}{c}\text { чоловіки } \\
(\mathrm{n}=11)\end{array}$ & $\begin{array}{c}\text { жінки } \\
(\mathrm{n}=17)\end{array}$ & $\begin{array}{c}\text { чоловіки } \\
(\mathrm{n}=14)\end{array}$ & $\begin{array}{c}\text { жінки } \\
(\mathrm{n}=18)\end{array}$ & $\begin{array}{c}\text { чоловіки } \\
(\mathrm{n}=10)\end{array}$ & $\begin{array}{c}\text { жінки } \\
(\mathrm{n}=10)\end{array}$ \\
\hline Жирова маса, \% & $21,17 \pm 0,44^{*}$ & $20,0 \pm 0,67^{*}$ & $27,71 \pm 1,22 * \wedge$ & $38,10 \pm 1,37^{* \wedge}$ & $24,34 \pm 0,54$ & $31,65 \pm, 48$ \\
\hline М'язова маса, кг & $38,35 \pm 2,37^{*}$ & $26,28 \pm 1,89 *$ & $34,72 \pm 2,35^{*}$ & $26,96 \pm 2,19 *$ & $41,02 \pm 2,54$ & $30,63 \pm 1,9$ \\
\hline Вміст рідини, \% & $49,64 \pm 2,65$ & $47,69 \pm 2,31$ & $50,12 \pm 3,0$ & $48,87 \pm 2,87$ & $52,25 \pm 2,33$ & $50,74 \pm 2,9$ \\
\hline Кісткова маса, \% & $11,71 \pm 1,0$ & $11,52 \pm 0,87$ & $12,07 \pm 1,04$ & $11,16 \pm 1,07$ & $11,62 \pm 1,23$ & $12,88 \pm 1,1$ \\
\hline ІМТ & $18,2 \pm 1,2 *$ & $19,6 \pm 0,33^{*}$ & $23,6 \pm 0,9$ & $22,7 \pm 0,25$ & $23,6 \pm 1,1$ & $22,8 \pm 0,8$ \\
\hline
\end{tabular}

Примітка. * - між показниками контрольної групи та в обстежених хворих виявлено статистично достовірну різницю - р<0,05; ^ - статистично достовірна різниця між показниками у хворих I та II груп - p<0,05. 
Огляди літератури, оригінальні дослідження, погляд на проблему, ювілеї

При аналізі наведених результатів біоімпедансного обстеження хворих на ХП показник IMT перебував у межах допустимої норми (20-25) у групи хворих на ХП з атеросклерозом та склав $23,6 \pm 0,9$ у чоловіків та $22,7 \pm 0,25-$ у жінок. У паці$\epsilon$ нтів I групи спостерігали дефіцит маси тіла за показником IMT, який перебував на рівні $18,2 \pm 1,2$ у чоловіків та 19,6 $\pm 0,33$ у жінок, що, ймовірно, можна пояснити синдромом мальабсорбції у хворих на ХП за наявності зовнішньосекреторної недостатності підшлункової залози. Проте, аналізуючи показники складу тіла, ми виявили дефіцит жирової маси у пацієнтів I групи $((21,17 \pm 0,44) \%$ у чоловіків та $(20,0 \pm 0,67) \%$ у жінок) та ії надмірний вміст у пацієнтів II групи $((27,71 \pm 1,22) \%$ у чоловіків та $(38,10 \pm 1,37) \%$ у жінок) при нормі 11,0-22,0 \% для чоловіків та 23,0-35,0 \% - для жінок відповідно. Натомість, у всіх обстежених пацієнтів відзначено дефіцит м'язової маси (при нормі 39,0-50,0 кг для чоловіків та 29,0-36,0 кг - для жінок). Це можна пояснити наявністю так званого «прихованого» ожиріння у хворих на ХП та атеросклероз, при якому спостерігається підвищення вмісту жирової маси паралельно зі зниженням вмісту м'язової маси на фоні нормального показника IMT. Вміст

\section{ЛІТЕРАТУРА}

1. Гаркуша С. Л. Досвід роботи кабінету корекції ліпідного спектра крові та лікування різних форм ожиріння у профілактиці виникнення захворювань системи кровообігу / С. Л. Гаркуша, В. Н. Корзун // Довкілля та здоров'я. - 2015. - 1 (72). - С. 31-34.

2. Губергриц Н. Б. Биоимпедансометрия у больных с хроническим панкреатитом с внешнесекреторной недостаточностью поджелудочной железы / Н. Б. Губергриц, О. А. Голубова // Экспериментальная и клиничес-

\section{REFERENCES}

1. Harkusha, S.L., \& Korzun, V.N. (2015). Dosvid roboty kabinetu korektsii lipidnoho spektra krovi ta likuvannia riznykh form ozhyrinnia u profilaktytsi vynyknennia zakhvoriuvan systemy krovoobihu [The experience of the office of correction of the lipid spectrum of blood and treatment of various forms of obesity in preventing the onset of circulatory system diseases]. Dovkillia ta zdorovia-Environment and Health, 1 (72), 31-34 [in Ukrainan].

2. Gubergrits, N.B., \& Golubova, O.A. (2014). Bioimpedansometriya u bolnykh s khronicheskym pankreatitom s vneshnesekretornoy nedostatochnostyu podzheludochnoy zhelezy [Bioimpedansometry in patients with chronic pancreatitis with exocrine pancreatic insufficiency]. Eksperymentalnaya i klinicheskaya gastroenterologiya- рідини та кісткова маса у всіх обстежуваних нами пацієнтів перебували в межах допустимих норм.

Отримані результати вказують на те, що у хворих на ХП та атеросклероз навіть при нормальному показнику IMT спостерігається ожиріння за результатами біоімпедансного дослідження складу тіла, що супроводжується тяжчим перебігом захворювання та, відповідно, несприятливим прогнозом для таких пацієнтів. Тому до комплексу заходів із діагностики ХП необхідно включати не тільки визначення показників ліпідного обміну та IMT, але й дослідження складу тіла (вміст жирової, м'язової, кісткової маси та рідини в організмі).

Висновки. 1. У хворих на хронічний панкреатит без атеросклеротичних змін виявлено дефіцит маси тіла за результатами біоімпедансного обстеження та IMT.

2. У хворих на хронічний панкреатит та атеросклероз відзначено «приховане» ожиріння за результатом біоімпедансного дослідження складу тіла при нормальному значенні IMT.

Перспективи подальших досліджень. Подальше вивчення показників складу тіла у хворих на ХП залежно від наявності атеросклеротичних змін. кая гастроэнтерология. - 2014. - № 5 (105). - С. 50.

3. Біоімпедансометрія в оцінці нутритивного статусу хворих на хронічні запальні захворювання кишечника / Ю. М. Степанов, Т. Й. Бойко, О. В. Сорочан [та ін.] // Гастроентерологія. - 2015. - № 2 (56). - С. 59-66.

4. Improving nutritional status assessment in patients with chronic pancreatitis / A. D. Hintaran, M. N. Chenault, B. P. M. Verhaegh [et al.] // Pancreatology. -2018. - Vol. 18, Issue 7. - P. 785-791.

Experimental and Clinical Gastroenterology, 5 (105), 50 [in Russian].

3. Stepanov, Yu.M., Boiko, T.Y., Sorochan, O.V., \& Stoikevych, M.V., \& Shkaredna, A.S. (2015). Bioimpedansometriia $v$ otsintsi nutrityvnoho statusu khvorykh na khronichni zapalni zakhvoriuvannia kyshechnyka [Bioimpedansometry in assessing the nutritional status of patients with chronic inflammatory bowel disease]. Hastroenterolohiia - Gastroenterology, 2 (56), 59-66 [in Ukrainian].

4. Hintaran, A.D., Chenault, M.N., Verhaegh, B.P.M., Reijven, P.L.M., Masclee, A.A.M., \& Keulemans, Y.C.A. (2018). Improving nutritional status assessment in patients with chronic pancreatitis. Pancreatology, 18 (7), 785791. 


\author{
๑Е. С. Сирчак, С. М. Опаленик, Н. Ю. Курчак
}

ГВУЗ «Ужгородский национальный университет»

PЕзЮМЕ. В статье описаны и проанализированы результаты биоимпедансометрии у больных хроническим панкреатитом и атеросклерозом.

Цель - исследовать особенности биоимпедансометрии у больных хроническим панкреатитом (ХП) и атеросклерозом.

Материал и методы. В исследование включено 60 больных ХП в возрасте от 40 до 60 лет. Контрольную группу составили 20 практически здоровых лиц в возрасте от 40 до 60 лет. В зависимости от наличия нарушений в липидограмме всех больных поделили на две группы. В первую вошли 28 больных ХП без атеросклеротических изменений, во вторую - 32 больных ХП и атеросклерозом. Всем больным было проведено исследование липидного спектра крови с определением уровня общего холестерина плазмы крови (ОХ), триглицеридов (ТГ), холестерина липопротеидов высокой плотности (ЛПВП) и липопротеидов низкой плотности (ЛПнП), коэффициента атерогенности (КА). Кроме того, всем больным было проведено биоимпедансное исследование состава тела с определением уровня жировой, мышечной, костной массы, жидкости в организме и расчетом индекса массы тела (ИМТ). Для интерпретации результатов исследования всех больных в зависимости от пола поделили на подгруппы.

Результаты. Полученные результаты свидетельствуют о том, что у больных ХП и атеросклерозом даже при нормальном показателе ИМТ наблюдается ожирение по результатам биоимпедансного исследования состава тела, что сопровождается более тяжелым течением заболевания и неблагоприятным прогнозом. Поэтому в комплекс мероприятий по диагностике ХП необходимо включать не только определение показателей липидного обмена и ИМТ, но и исследование состава тела.

Выводы. Всем больным было проведено исследование липидного спектра крови с определением уровня общего холестерина плазмы крови (ОХ), триглицеридов (ТГ), холестерина липопротеидов высокой плотности (ЛПВП) и липопротеидов низкой плотности (ЛПНП), коэффициента атерогенности (КА). Также всем больным было проведено биоимпедансное исследование состава тела с определением уровня жировой, мышечной, костной массы, жидкости в организме и расчетом индекса массы тела (ИМТ).

В ходе исследования был выявлен дефицит массы тела по результатам биоимпедансного обследования и ИМТ у пациентов с хроническим панкреатитом без атеросклеротических изменений. У пациентов с хроническим панкреатитом и атеросклерозом было установлено “скрытое» ожирение по результатам биоимпедансометрии при нормальном значении ИМТ.

КЛючЕВЫЕ СЛОВА: хронический панкреатит; атеросклероз; биоимпедансное исследование.

\title{
FEATURES OF BIOIMPEDANSOMETRY IN PATIENTS WITH CHRONIC PANCREATITIS AND ATHEROSCLEROSIS
}

\section{@Ye. S. Sirchak, S. M. Opalenyk, N. Yu. Kurchak Uzhhorod National University}

SUMMARY. The results of bioimpedansometry in patients with chronic pancreatitis and atherosclerosis were studied.

The aim - research the features of bioimpedansometry in patients with chronic pancreatitis (CP) and atherosclerosis.

Material and Methods. The study included 60 patients with CP in age from 40 to 60 years. The control group consisted of 20 healthy individuals aged from 40 to 60 years. Depending on the presence of violations in the lipid profile, all patients were divided into two groups. The group 1 included 28 patients with CP without atherosclerotic changes, the group 2-32 patients with CP and atherosclerosis. All patients were tested for blood lipid spectrum with the determination of total blood plasma cholesterol (TC), triglycerides (TG), high-density lipoprotein cholesterol (HDL) and low-density lipoprotein cholesterol (LDL), atherogenic coefficient (CA). In addition, all patients underwent bioimpedance studies of body composition with the determination of the level of fat, muscle, bone mass, body fluids and calculation of body mass index (BMI). To interpret the results of the study, all patients were subdivided according to gender.

Results. The results suggest that in patients with CP and atherosclerosis, even with a normal indicator of BMI, obesity is observed according to the results of bioimpedance studies of body composition, which is accompanied by a more severe course of the disease and an unfavorable prognosis. Therefore, the complex of measures for the diagnosis of CP should include not only the definition of lipid metabolism and BMI, but also the study of body composition.

Conclusions. All patients were tested for blood lipid spectrum with the determination of total blood plasma cholesterol (TC), triglycerides (TG), high-density lipoprotein cholesterol (HDL) and low-density lipoprotein (LDL) cholesterol (AT). Also, all patients underwent bioimpedance study of body composition with the determination of the level of fat, muscle, bone mass, body fluids and calculation of body mass index (BMI).

The study revealed a lack of body mass according to the results of bioimpedance examination and BMI in patients with chronic pancreatitis without atherosclerotic changes. In patients with chronic pancreatitis and atherosclerosis, "latent" obesity was established according to the results of bio-impedancemetry with a normal value of BMI.

KEY WORDS: chronic pancreatitis; atherosclerosis; bioimpedance examination. 